\title{
PEMBELAJARAN DARING TEKS EKSPOSISI DENGAN MEDIA AUDIO VISUAL PADA MATA PELAJARAN BAHASA INDONESIA KELAS VIII SMPN 1 SEWON
}

\author{
Dewi Azizah Damaryanti, Iis Suwartini \\ Fakultas Keguruan dan Ilmu Pendidikan Universitas Ahmad Dahlan \\ dezahdamaryanti@gmail.com, iis.suwartini@pbsi.uad.ac.id
}

\begin{abstract}
ABSTRAK
Tujuan penelitian ini untuk menjelaskan pelaksanaan kegiatan pembelajaran daring teks eskposisi dengan media audio visual pada mata pelajaran Bahasa Indonesia kelas VIII SMPN 1 Sewon. Metode penelitian yang digunakan yaitu deskriptif kualitatif dengan teknik observasi. Penelitian ini menggunakan instrumen lembar observasi dan tes. Hasil yang diperoleh dari penelitian ini yaitu (1) proses pembelajaran daring teks eksposisi dengan media audio visual di kelas VIII SMPN 1 Sewon dimulai dari tahap persiapan penyusunan perangkat pembelajaran, pelaksanaan kegiatan pembelajaran, penugasan, dan penyerahan nilai, (2) pengaruh media audio visual yang berisi materi teks eksposisi terhadap hasil belajar siswa kelas VIII SMPN 1 Sewon memperoleh nilai rata-rata sebesar 68,91 (3) terdapat beberapa faktor yang mempengaruhi berlangsungnya kegiatan pembelajaran daring materi teks eksposisi dengan menggunakan media audio visual yaitu sebagaian siswa tidak mengerjakan tugas sehingga berdampak pada nilai rata-rata yang kurang baik, penulis sebagai asisten guru dan guru pamong kurang tegas ketika mengingatkan siswa untuk segera mengerjakan tugas, dan beberapa siswa kurang memahami konsep materi teks eksposisi dikarenakan adanya kendala masalah kuota internet, masalah jaringan internet, dan masalah penggunaan gawai.
\end{abstract}

Kata kunci : Pembelajaran Daring, Teks Eksposisi, Media Audio Visual, Bahasa Indonesia

\section{PENDAHULUAN}

Era pandemi Covid-19 telah merubah segala bidang kehidupan. Termasuk di bidang pendidikan Indonesia yang ikut terkena dampak dari pandemi tersebut. Segala bentuk kegiatan pembelajaran tidak lagi dilaksanakan secara tatap muka antara guru dengan siswa, melainkan harus dilaksanakan secara daring. Hal yang demikian mengharuskan adanya bentuk penguasaan teknologi digital demi kepentingan belajar dan mengajar.

Kendala yang seperti itu lantas mengakibatkan segala sesuatu yang penting dalam urusan pendidikan, mau tak mau harus berjalan tanpa adanya unsur penundaan. Termasuk pelaksanaan kegiatan Pengenalan Lapangan Persekolahan II (PLP II) yang tetap dilaksanakan secara daring oleh tim P3K Fakultas Keguruan dan Ilmu Pendidikan serta Fakultas Agama Islam (khususnya Program Studi Pendidikan Agama Islam) Universitas Ahmad Dahlan.

Kegiatan PLP II memiliki berbagai rangkaian kegiatan. Penelitian ini fokus membahas pada bagian kegiatan pembelajaran daring yang dilaksanakan oleh penulis di kelas VIII SMPN 1 Sewon.

Kaitannya dengan kegiatan pembelajaran, guna memperjelas isi jurnal penelitian ini, maka perlu diketahui terlebih dahulu tentang konsep pembelajaran 
berdasarkan teori yang relevan. Teori pembelajaran telah dijelaskan dalam isi Undang-Undang Nomor 20 tahun 2003 pasal 1 ayat 20 tentang sistem pendidikan nasional yang menyatakan bahwa pembelajaran adalah posisi di mana pendidik dan peserta didik dipertemukan dalam satu lingkungan belajar yang melibatkan sumber belajar sehingga terjadi interaksi di antara ketiganya. Hal ini selaras dengan pendapatnya Uno (2012: 2) dalam bukunya yang berjudul Perencanaan Pembelajaran menjelaskan bahwa pembelajaran pada hakikatnya bertujuan untuk membelajarkan peserta didik. Demi mencapai tujuan tersebut, diperlukan adanya keterlibatan pendidik dan adanya interaksi dari sumber belajar yang dipakai.

Pada proses kegiatannya, penulis melaksanakan praktik mengajar secara daring dan mengampu KD 3.5 dan KD 4.5 Bab 3 Teks Eksposisi kelas VIII SMPN 1 Sewon dengan berlandaskan pada kurikulum 2013 revisi 2018. Bagian tersebut telah ditetapkan oleh Guru Pamong. Jadi, tidak ada unsur subjektivitas dari penulis ketika memilih materi ajar dalam pelaksanaan pembelajaran daring.

Segala bentuk kegiatan pembelajaran dari mulai tahap pembuka sampai dengan penutup dilaksanakan secara daring dengan menyesuaikan jenis platform yang digunakan. Ada banyak pilihan platform yang cocok digunakan untuk kegiatan pembelajaran jarak jauh/daring. Pemilihan platform tersebut disesuaikan dengan kapasitas, kemampuan, dan keterbatasan yang dimiliki oleh guru dan siswa.

Penggunaan platform yang telah ditentukan oleh pihak SMPN 1 Sewon, yakni meggunakan WhatsApp Group, Google Classroom, Google Quiz, dan Youtube. Setelah itu, barulah kegiatan pembelajaran daring dapat dilaksanakan sesuai dengan jadwal, termasuk pembelajaran daring dengan media audio visual yang membahas materi tentang teks eksposisi kelas VIII SMPN 1 Sewon. Perlu diketahui bahwa platform ini berbeda dengan media pembelajaran audio visual.

Media pembelajaran menurut Arsyad (2011: 23) yaitu sebuah alat yang digunakan untuk membantu kelancaran selama kegiatan pembelajaran berlangsung yang di dalamnya mengandung materi dan intruksi yang dapat digunakan oleh siswa untuk belajar. Teori lain dikemukakan oleh Briggs dalam Riyana (2012: 10) yang dengan singkat menjelaskan bahwa media pembelajaran adalah sarana penyalur konten materi pembelajaran yang bisa saja berwujud buku, video, slide, dan lain-lain. Sama halnya dengan penelitian ini yang membahas tentang media pembelajaran audio visual. Formatnya berupa audio (dapat didengar) dan visual (dapat disaksikan) atau dengan kata lain video.

Berdasarkan asumsi tersebut, maka penelitian ini penting dilakukan untuk mendeskripsikan lebih rinci mengenai pembelajaran daring yang membahas materi tentang teks eksposisi pada mata pelajaran Bahasa Indonesia kelas VIII SMPN 1 Sewon. Berbagai pemaparan informasi yang objektif sesuai dengan data lapangan nantinya akan tersaji di dalam penelitian ini.

Selain itu, adapun beberapa masalah yang akan dipecahkan dan dibahas dalam penelitian ini. Penulis menetapkan rumusan masalah yang terdiri dari tiga poin, di antaranya : (1) Bagaimana proses pembelajaran daring teks eksposisi dengan media audio visual mata pelajaran Bahasa Indonesia kelas VIII SMPN 1 Sewon? (2) Bagaimana pengaruh media audio visual yang berisi materi teks eksposisi terhadap hasil belajar siswa kelas VIII SMPN 1 Sewon? (3) Apa saja faktor-faktor yang mempengaruhi berlangsungnya kegiatan pembelajaran daring teks eksposisi dengan media audio visual mata pelajaran Bahasa Indonesia kelas VIII SMPN 1 Sewon? 
Penelitian yang demikian memiliki relevansi dengan penelitian terdahulu. Hal ini bukan berarti penulis melakukan plagiasi. Maksudnya yaitu sebelum penelitian ini dilakukan, sudah ada peneliti lain yang pembahasannya mirip dengan judul penelitian ini. Berikut adalah rinciannya :

1. Sari, dkk. (2014) meneliti "Pembelajaran Menulis Teks Eksposisi pada Siswa Kelas VII SMP Xaverius 3 Bandarlampung".

Persamaan penelitian tersebut dengan penelitian ini dapat dilihat dari aspek tujuan penelitian yang sama-sama menjelaskan tentang proses pembelajaran teks eksposisi dari mulai tahap persiapan perangkat pembelajaran, aktivitas guru dan siswa, serta penilaian pembelajaran. Selain itu adapun persamaan metode yang digunakan yaitu deksriptif kualitatif. Selain persamaan, adapun perbedaan antara penelitian terdahulu dengan penelitian ini. Perbedaan tersebut dapat dilihat dari segi hasil penelitian. Penelitian terdahulu dinyatakan bahwa komponen yang tercantum di dalam RPP dinyatakan sesuai, tetapi pada komponen penilaian masih kurang sesuai, sedangkan pada penelitian ini kaitannya dengan RPP semua itu tidak ada masalah di bagian komponennya.

2. Amalia, dkk. (2018) meneliti "Pengaruh Model Discovery Learning Berbantuan Media Audio Visual Terhadap Keterampilan Menulis Teks Eksposisi Siswa Kelas VIII SMP Negeri 31 Padang”.

Persamaan dari penelitian tersebut dengan penelitian ini adalah samasama menggunakan media audio visual untuk pembelajaran menulis teks eksposisi kelas VII SMP. Kemudian adapun persamaan instrumen tes yang diberikan kepada siswa. Selain persamaan, ada pun perbedaan dari kedua penelitian ini, yaitu berbeda dari segi hasil penelitian. Penelitian terdahulu dinyatakan sukses dengan perolehan nilai rata-rata 82,84 dari 34 siswa kelas VII SMP. Berbeda dengan penelitian ini yang mana nilai rata-rata hasil belajar siswa hanya sebesar 68,91 .

3. Ferenna, dkk. (2020) meneliti "Pembelajaran Teks Eksposisi Peserta Didik Kelas VIII SMP Negeri 5 Banjarmasin".

Persamaan dari penelitian tersebut dengan penelitian ini adalah samasama membahas tentang pembelajaran teks eksposisi untuk siswa kelas VIII SMP yang meliputi tahap perencanaan, pelaksanaan, dan penilaian. Metode yang digunakan yaitu sama-sama deskriptif yang mengolah data kuantitatif. Kemudian ada juga persamaan teknik observasi yang digunakan. Ditinjau dari segi hasil, keduanya sama-sama mendapat perolehan nilai hasil belajar siswa di bawah KKM karena siswa kurang memahami materi teks eksposisi dengan baik. Selain persamaan, ada pun perbedaan di antara kedua penelitian ini. Penelitian terdahulu lebih kompleks memilih teknik observasi yang digabung dengan teknik wawancara dan dokumentasi. Hal itu berbeda dengan penelitian ini yang hanya menggunakan teknik observasi saja, itu pun dilakukan secara daring.

\section{METODE PENELITIAN}

Jenis penelitian ini adalah penelitian deskriptif yang mengolah data kualitatif. Penjelasan deskriptif diharapkan mampu mengulas setiap detail dari masing-masing data. Setiap data yang tertulis dalam penelitian ini adalah data yang murni bersumber dari pemilihan sampel dan objek penelitian tanpa dimanipulasi. 
Tujuannya tak lain untuk mematuhi kaidah penulisan penelitian yang sifatnya ilmiah dan objektif.

Kembali lagi pada pembahasan jenis penelitian yaitu deskriptif kualitatif. Deskriptif kualitatif menurut Sugiyono (2013: 9) yaitu suatu metode dalam penelitian yang digunakan untuk meneliti keadaan objek secara alamiah (berdasarkan pada kenyataan sebenarnya).

Penelitian deskriptif kualitatif secara umum bukanlah penelitian yang berdasarkan pada dunia yang seharusnya, tetapi jenis penelitian ini dilandasi adanya fenomena nyata dengan cara melihat fakta dunia yang apa adanya. Fenomena nyata itu disebut data.

Berdasarkan pemilihan metode tersebut, kemudian lanjut ke penggunaan teknik yang digunakan untuk menjaring dan menganalisis data. Teknik yang digunakan adalah observasi di lapangan secara daring. Observasi itu sendiri adalah sebuah teknik yang sistematis di mana peneliti melakukan pengamatan secara menyeluruh dan mampu memahami pola perilaku dalam situasi yang diteliti (Tersiana, 2018: 12). Berdasarkan pemilihan teknik tersebut, maka instrumen yang digunakan dalam penelitian ini adalah lembar observasi dan tes.

Pengertian dari istilah instrumen itu sendiri pernah dijelaskan oleh Arikunto (2013: 203) yang menyatakan bahwa instrumen penelitian adalah sebuah alat yang dapat membantu atau mempermudah penelitian khususnya ketika mengumpulkan data. Tujuannya supaya data-data tersebut dapat tersusun secara sistematis. Hal yang sama dicetuskan oleh Sanjaya (2015: 246-247) menyatakan bahwa instrumen adalah alat bantu dalam kegiatan penelitian sehingga peneliti dapat mengumpulkan data-data empiris. Empiris dalam artian data-data tersebut dikumpulkan sesuai dengan hasil penemuan dan pengamatan.

Pada bagian metode, dijelaskan pula mengenai sampel dan objek penelitian. Sugiyono (2013: 81) menyatakan bahwa sampel penelitian adalah bagian dari keseluruhan populasi dengan karakteristik tertentu yang dipilih berdasarkan pertimbangan yang ada. Penulis menetapkan seluruh siswa kelas VIII A - VIII D SMPN 1 Sewon sebagai sampel penelitian.

Berikut adalah pemaparan display data yang tersaji dalam bentuk tabel.

Tabel 1. Sampel Data Penelitian.

\begin{tabular}{|c|c|c|}
\hline Nama Sekolah & Kelas & Jumlah \\
\hline SMPN 1 & VIII A & 32 \\
\cline { 2 - 3 } Sewon & VIII B & 31 \\
\cline { 2 - 3 } & VIII C & 32 \\
\cline { 2 - 3 } & VIII D & 32 \\
\hline & Jumlah & 127 \\
\hline
\end{tabular}

Data di atas menjelaskan sampel penelitian yang melibatkan seluruh siswa kelas VIII A - VIII D SMPN 1 Sewon dalam kegiatan pembelajaan daring teks eksposisi dengan media audio visual pada mata pelajaran Bahasa Indonesia. Rincian jumlah sampel penelitiannya adalah sebagai berikut.

1. Kelas VIII A sebanyak 32 siswa

2. Kelas VIII B sebanyak 31 siswa

3. Kelas VIII C sebanyak 32 siswa

4. Kelas VIII D sebanyak 32 siswa

5. Jumlah keseluruhan $=127$ siswa 
Perlu diketahui bahwa istilah sampel penelitian sering disandingkan dengan objek penelitian. Masih dari ahli yang sama, Sugiyono (2013: 121) menjelaskan bahwa objek penelitian merupakan suatu analisis yang dilakukan guna memperoleh gambaran umum dan menyeluruh atas situasi tertentu yang diteliti. Situasi tersebut bisa mencangkup beberapa perkara yang akan diulas dan dipecahkan dalam penelitian.

Berdasarkan penjelasan tersebut, maka objek dalam penelitian ini adalah (1) Proses pembelajaran daring teks eksposisi dengan media audio visual mata pelajaran Bahasa Indonesia kelas VIII SMPN 1 Sewon, (2) Pengaruh media audio visual yang berisi materi teks eksposisi terhadap hasil belajar siswa kelas VIII SMPN 1 Sewon, dan (3) Faktor-faktor yang mempengaruhi berlangsungnya kegiatan pembelajaran daring teks eksposisi dengan media audio visual mata pelajaran Bahasa Indonesia kelas VIII SMPN 1 Sewon.

Pada prosesnya, penelitian ini bertempat di rumah penulis. Hal ini dilakukan dalam rangka mematuhi aturan social distancing dan stay at home selama pandemi Covid-19 belum berakhir. Kemudian perihal waktu penelitian, penelitian ini berlangsung selama satu bulan sesuai dengan rentang waktu pelaksanaan kegiatan PLP II oleh pihak P3K FKIP UAD.

\section{HASIL DAN PEMBAHASAN}

Berdasarkan ketiga rumusan masalah yang telah dipaparkan pada bagian sebelumnya, maka pada bagian ini akan dikemukakan hasil dan pembahasan atas jawaban dari tiga poin rumusan masalah tersebut.

1. Proses pembelajaran daring teks eksposisi dengan media audio visual mata pelajaran Bahasa Indonesia kelas VIII SMPN 1 Sewon

Pada prosesnya, tentu diawali dengan tahap perencanaan. Guru harus mempersiapkan segala macam perangkat pembelajaran yang meliputi; RPP, media pembelajaran, bahan ajar, evaluasi (lembar LKS dan kunci jawaban), serta asesmen atau rubrik penilaian.

Meskipun fokus pembahasan pada jurnal artikel ini adalah mengacu pada penggunaan media pembelajaran dalam kegiatan pembelajaran daring, tetapi rangkaian perangkat pendukung harus tetap dibuat. Kembali lagi pada proses pembelajaran daring yang menggunakan media audio visual (video). Media tersebut dipilih oleh penulis dikarenakan di dalam buku panduan PLP II, jenis media audio visual tergolong dalam daftar kriteria pembuatan media pembelajaran. Penulis menciptakan media audio visual secara mandiri dan tentunya berpedoman pada buku guru dan buku siswa kelas VIII SMP.

Isi yang terkandung di dalam media audio visual teks eksposisi di antaranya; pengertian teks eksposisi, ciri-ciri teks eksposisi, struktur teks eksposisi, pola pengembangan teks eksposisi, jenis paragraf teks eksposisi, dan keterampilan menyimpulkan teks eksposisi. Keenam sub bab tersebut disesuaikan dengan KD 3.5 dan KD 4.5 Bab 3 yang berjudul Teks Eksposisi dalam Media Massa.

Setelah selesai menciptakan media audio visual yang berisi materi teks eksposisi, kemudian hasilnya diunggah di kanal Youtube milik penulis. Link media https://youtu.be/ndzfvoBuyNc.

Pada prosesnya, penulis membagikan link video tersebut di WhatsApp Group pada saat kegiatan pembelajaran daring. Hanya dengan satu kali klik, 
siswa sudah bisa menyimak tayangan video pembelajaran tentang teks eksposisi. Sangat mudah dan praktis. Selain itu, tujuan dari penggunaan media pembelajaran ini selaras dengan pemanfaatan teknologi digital di era pandemi Covid-19.

Tak hanya melalui media audio visual saja, sebetulnya penulis juga membagikan materi tekstual di Google Classroom yang kandungan isi materinya sama dengan apa yang ada di media video. Alasannya adalah karena terkadang siswa maih memerlukan materi tekstual untuk kepentingan belajar mereka di samping penggunaan media audio visual.

Kegiatan pembelajaran yang demikian dilaksanakan sebanyak empat kali di empat rombel kelas yang berbeda. Rinciannya : pertemuan pertama di kelas VIII A, pertemuan pertama di kelas VIII B, pertemuan pertama di kelas VIII C, dan pertemuan pertama di kelas VIII D.

2. Pengaruh media audio visual yang berisi materi teks eksposisi terhadap hasil belajar siswa kelas VIII SMPN 1 Sewon

Pembahasan mengenai bagaimana pengaruh dari pengunaan media audio visual yang berisi materi teks eksposisi terhadap hasil belajar siswa tentu harus dijelaskan dengan penyajian data berupa rekapitulasi daftar nilai. Hal ini adalah satu-satunya cara untuk menunjukkan tanda bukti yang objektif.

Setelah kegiatan pembelajaran daring (khususnya pada pertemuan pertama) selesai, hal yang selanjutnya dilakukan oleh guru yaitu memberikan penugasan kepada siswa. Penugasan dibuat dalam bentuk soal pilihan ganda dan essai yang harus dikerjakan oleh siswa melalui laman Google Quiz.

Link tugas :

https://docs.google.com/forms/d/e/1FAIpQLSd2yhVe2vUATYqcRgxvkUU5P s6PGVhP3v4U5iaSwlELmnM85w/viewform

Berikut akan disajikan rekapitulasi daftar nilai tugas bab 3 materi teks eksposisi siswa kelas VIII A - VIII D SMPN 1 Sewon.

Tabel 2. Data Rekapitulasi Nilai Tugas

\begin{tabular}{cccc}
\hline Kelas & Nilai & $\begin{array}{c}\text { Jumlah } \\
\text { Siswa }\end{array}$ & $\begin{array}{c}\text { Total } \\
\text { Nilai }\end{array}$ \\
\hline A & 0 & 2 & 0 \\
\hline A & 30 & 1 & 30 \\
\hline A & 34 & 1 & 34 \\
\hline A & 46 & 1 & 46 \\
\hline A & 54 & 1 & 54 \\
\hline A & 60 & 1 & 60 \\
\hline A & 64 & 1 & 64 \\
\hline A & 66 & 1 & 66 \\
\hline A & 68 & 1 & 68 \\
\hline A & 72 & 1 & 72 \\
\hline A & 78 & 1 & 78 \\
\hline A & 80 & 2 & 160 \\
\hline A & 82 & 2 & 164 \\
\hline A & 84 & 1 & 84 \\
\hline A & 86 & 2 & 172 \\
\hline
\end{tabular}




\begin{tabular}{|c|c|c|c|}
\hline $\mathrm{A}$ & 88 & 6 & 528 \\
\hline $\mathrm{A}$ & 90 & 5 & 450 \\
\hline A & 92 & 2 & 184 \\
\hline $\mathrm{B}$ & 28 & 1 & 28 \\
\hline B & 30 & 1 & 30 \\
\hline B & 34 & 1 & 34 \\
\hline B & 60 & 1 & 60 \\
\hline $\mathrm{B}$ & 62 & 1 & 62 \\
\hline $\mathrm{B}$ & 66 & 1 & 66 \\
\hline $\mathrm{B}$ & 68 & 1 & 68 \\
\hline B & 72 & 1 & 72 \\
\hline B & 80 & 1 & 80 \\
\hline $\mathrm{B}$ & 82 & 4 & 328 \\
\hline $\mathrm{B}$ & 84 & 2 & 168 \\
\hline $\mathrm{B}$ & 86 & 8 & 688 \\
\hline B & 88 & 6 & 528 \\
\hline B & 90 & 1 & 90 \\
\hline B & 92 & 1 & 92 \\
\hline $\mathrm{C}$ & 0 & 3 & 0 \\
\hline $\mathrm{C}$ & 32 & 1 & 32 \\
\hline $\mathrm{C}$ & 38 & 1 & 38 \\
\hline $\mathrm{C}$ & 44 & 1 & 44 \\
\hline $\mathrm{C}$ & 46 & 1 & 46 \\
\hline $\mathrm{C}$ & 52 & 1 & 52 \\
\hline $\mathrm{C}$ & 58 & 1 & 58 \\
\hline $\mathrm{C}$ & 62 & 1 & 62 \\
\hline $\mathrm{C}$ & 66 & 2 & 132 \\
\hline Kelas & Nilai & $\begin{array}{l}\text { Jumlah } \\
\text { Siswa }\end{array}$ & $\begin{array}{l}\text { Total } \\
\text { Nilai }\end{array}$ \\
\hline $\mathrm{C}$ & 68 & 1 & 68 \\
\hline $\mathrm{C}$ & 70 & 1 & 70 \\
\hline $\mathrm{C}$ & 72 & 2 & 144 \\
\hline $\mathrm{C}$ & 76 & 3 & 228 \\
\hline $\mathrm{C}$ & 78 & 2 & 156 \\
\hline $\mathrm{C}$ & 80 & 5 & 400 \\
\hline $\mathrm{C}$ & 86 & 1 & 86 \\
\hline $\mathrm{C}$ & 88 & 4 & 325 \\
\hline $\mathrm{C}$ & 90 & 1 & 90 \\
\hline $\mathrm{D}$ & 0 & 6 & 0 \\
\hline $\mathrm{D}$ & 48 & 1 & 48 \\
\hline $\mathrm{D}$ & 56 & 2 & 112 \\
\hline $\mathrm{D}$ & 60 & 1 & 60 \\
\hline $\mathrm{D}$ & 64 & 1 & 64 \\
\hline $\mathrm{D}$ & 66 & 1 & 66 \\
\hline $\mathrm{D}$ & 70 & 1 & 70 \\
\hline $\mathrm{D}$ & 74 & 3 & 222 \\
\hline
\end{tabular}




\begin{tabular}{cccc}
\hline $\mathrm{D}$ & 76 & 1 & 76 \\
\hline $\mathrm{D}$ & 78 & 2 & 156 \\
\hline $\mathrm{D}$ & 80 & 3 & 240 \\
\hline $\mathrm{D}$ & 82 & 2 & 164 \\
\hline $\mathrm{D}$ & 86 & 2 & 172 \\
\hline $\mathrm{D}$ & 88 & 2 & 176 \\
\hline $\mathrm{D}$ & 90 & 4 & 360 \\
\hline & & Jumlah & 8752 \\
\hline & & Rata-rata & 68,91 \\
\hline
\end{tabular}

Berdasarkan data di atas, berikut adalah nilai rata-rata dari keseluruhan sampel penelitian untuk mendeskripsikan hasil belajar siswa kaitannya dengan pengaruh media audio visual yang berisi materi teks eksposisi pada pembelajaran Bahasa Indonesia kelas VIII A- VIII D SMPN 1 Sewon.

Rumus mean $=\frac{\text { jumlah keseluruhan data }}{\text { banyaknya data }}=n$

\section{$\frac{8752}{127}=68,91339$}

Hasil tersebut dibulatkan menjadi $\underline{68,91}$

Dilihat dari nilai rata-rata yang diperoleh, dapat dikatakan bahwa nilai 68,91 masih termasuk kurang baik, sebab kriteria mean yang baik adalah minimal 75,00. Jika dianalisis satu per satu, memang sudah banyak siswa yang memperoleh nilai di atas KKM yakni 75,00. Tetapi adapun siswa yang mendapat nilai 0 karena mereka tidak mengerjakan tugas meskipun sudah diingatkan kembali oleh guru. Hal seperti ini akan berdampak pada perhitungan nilai rata-rata dari keempat rombel kelas.

Masalah yang demikian disebabkan oleh berbagai kendala yang terjadi. Pada sub bab berikutnya penulis akan menjawab dan membahas lebih lanjut rumusan masalah mengenai faktor-faktor yang mempengaruhi berlangsungnya kegiatan pembelajaran daring teks eksposisi dengan media audio visual sehingga berdampak pada nilai rata-rata yang kurang baik.

3. Faktor-faktor yang mempengaruhi berlangsungnya kegiatan pembelajaran daring teks eksposisi dengan media audio visual mata pelajaran Bahasa Indonesia kelas VIII SMPN 1 Sewon.

Ditinjau dari pembahasan sebelumnya, telah diketahui bahwa nilai rata-rata yang diperoleh adalah 68,91. Nilai tersebut masuk dalam kategori kurang baik. Nilai rata-rata yang dikatakan baik sesuai dengan ketetapan KKM yakni 75,00. Masalah yang demikian disebabkan oleh berbagai faktor, di antaranya:

a. Berdasarkan hasil penelitian, terdapat beberapa siswa yang tidak mengirimkan jawaban tugas sampai pada deadline yang telah ditentukan. Padahal penulis sebagai asisten guru sudah memberi toleransi waktu kepada mereka yang terlambat mengerjakan tugas, tetapi tetap saja tugas tersebut tidak dikerjakan. Hal ini mengakibatkan sebagian siswa tidak mendapat nilai. Guru selalu memberikan nilai yang objektif kepada siswa. Jadi, apabila tugas tidak dikerjakan maka nilainya adalah 0 .

b. Penulis sebagai asisten guru dan guru pamong kurang tegas ketika mengingatkan siswa untuk segera mengirim jawaban tugas. Hal ini dikarenakan penulis selalu memikirkan kendala yang dialami siswa terkait 
masalah kuota, HP dan laptop yang masih bergantian dengan teman dan orang tua mereka, serta masalah jaringan internet. Jadi, penulis berusaha mengingatkan mereka untuk mengirim jawaban tugas tanpa adanya unsur ancaman atau paksaan. Namun dampak buruknya adalah masih ada sebagain siswa yang tetap tidak mengerjakan tugas.

c. Terdapat beberapa siswa yang kurang memahami konsep materi teks eksposisi. Hal ini dikarenakan kegiatan pembelajaran daring yang bersifat real time dan tidak diperbolehkan antara guru dan siswa untuk bertatap muka secara langsung. Meskipun sekarang ini sudah ada platform rapat online yang bisa digunakan untuk kegiatan pembelajaran seperti contohnya Google Meet dan Zoom, namun di SMPN 1 Sewon belum bisa menggunakan platform tersebut. Alasannya adalah karena faktor kondisi ekonomi siswa yang berbeda-beda. Selain itu, pihak sekolah dan guru merasa kasihan ketika semua siswa diharuskan belajar online melalui platform Google Meet atau Zoom yang cenderung boros kuota. Jadi, dengan terpaksa kegiatan pembelajaran daring di SMPN 1 Sewon dilaksanakan menggunakan platform WhatsApp Group (untuk kegiatan pembelajaran daring dari mulai pembuka sampai penutup), Google Classroom (untuk pengiriman materi tekstual), Google Quiz (untuk penugasan), dan Youtube (khusus untuk upload media audio visual).

d. Berdasarkan faktor pada poin b, masalah tersebut mengakibatkan siswa kesulitan memahami materi. Terkadang siswa yang sudah terbiasa belajar secara tatap muka bersama gurunya akan lebih mudah memahami materi, tetapi kali ini sedikit berbeda. Melalui kegiatan pembelajaran daring, guru harus lebih ekstra ketika berusaha menjelaskan materi, begitupun dengan siswa yang harus lebih mandiri dan berusaha sungguh-sungguh untuk memahami materi yang disampaikan oleh guru dalam kegiatan pembelajaran daring.

\section{SIMPULAN}

Berdasarkan hasil penelitian dan pembahasannya, maka diperoleh kesimpulan bahwa (1) proses pembelajaran daring teks eksposisi dengan media audio visual di kelas VIII SMPN 1 Sewon diawali dengan tahap persiapan penyusunan perangkat pembelajaran. Setelah itu, barulah dilaksanakan kegiatan pembelajaran sampai dengan tahap penugasan dan pemberian nilai kepada siswa, (2) penggunaan media audio visual pada pembelajaran daring materi teks eksposisi kelas VIII SMPN 1 Sewon berdampak langsung pada nilai rata-rata yang diperoleh yaitu 68,91. Nilai tersebut masuk dalam kategori kurang baik, (3) terdapat beberapa faktor yang mempengaruhi berlangsungnya kegiatan pembelajaran daring materi teks eksposisi dengan menggunakan media audio visual yaitu masih ada sebagaian siswa yang tidak mengerjakan tugas sehingga berdampak pada nilai rata-rata yang kurang baik, penulis sebagai asisten guru dan guru pamong kurang tegas ketika mengingatkan siswa untuk segera mengirim jawaban tugas, dan terdapat beberapa siswa yang kurang memahami konsep materi teks eksposisi dikarenakan adanya kendala yang dialami oleh siswa seperti masalah kuota internet, masalah jaringan internet, dan masalah penggunaan gawai yang sebagaian siswa masih harus bergantian dengan teman dan orang tuanya. 


\section{DAFTAR PUSTAKA}

Amalia, F., Syahrul, R., \& Arief, E. (2018). Pengaruh Model Discovery Learning Berbantuan Media Audiovisual Terhadap Keterampilan Menulis Teks Eksposisi Siswa Kelas VII SMP Negeri 31 Padang. Jurnal Pendidikan Bahasa dan Sastra Indonesia, 7(1).

Arikunto, S. (2013). Prosedur Penelitian: Suatu Pendekatan Praktik. Jakarta: Rineka Cipta.

Arsyad, A. (2011). Media Pembelajaran. Jakarta: PT Raja Grafindo Persada.

Ferenna, Kusasi, Z. A., \& Faradina. (2020). Pembelajaran Teks Eksposisi Peserta Didik Kelas VIII SMP Negeri 5 Banjarmasin. Locana: Jurnal Tugas Akhir Mahasiswa, 3(1).

Riyana, C. (2012). Media Pembelajaran. Jakarta: Direktorat Jenderal Pendidikan Islam Kementrian Agama Republik Indonesia.

Sanjaya, W. (2015). Perencanaan dan Desain Sistem Pembelajaran. Jakarta: Kencana.

Sari, D., Agustina, E. S., \& Suliani, N. N. W. (2014). Pembelajaran Menulis Teks Eksposisi pada Siswa Kelas VII SMP Xaverius 3 Bandarlampung. Jurnal Kata, 2(4).

Sugiyono. (2013). Metode Penelitian Kuantitatif, Kualitatif, dan R\&D. Bandung: Alfabeta.

Tersiana, A. (2018). Metode Penelitian. Yogyakarta: Gramedia Pustaka.

Uno, H. B. (2012). Perencanaan Pembelajaran. Jakarta: Bumi Aksara. 